University of Nebraska - Lincoln

DigitalCommons@University of Nebraska - Lincoln

Faculty Publications from Nebraska Center for

Materials and Nanoscience, Nebraska Center Materials and Nanoscience

for (NCMN)

6-2005

\title{
JECP/HOLZ - An interactive computer program for simulation of HOLZ patterns
}

Xingzhong Li

University of Nebraska - Lincoln, xli2@unl.edu

Follow this and additional works at: https://digitalcommons.unl.edu/cmrafacpub

Part of the Nanoscience and Nanotechnology Commons

$\mathrm{Li}$, Xingzhong, "JECP/HOLZ - An interactive computer program for simulation of HOLZ patterns" (2005). Faculty Publications from Nebraska Center for Materials and Nanoscience. 106.

https://digitalcommons.unl.edu/cmrafacpub/106

This Article is brought to you for free and open access by the Materials and Nanoscience, Nebraska Center for (NCMN) at DigitalCommons@University of Nebraska - Lincoln. It has been accepted for inclusion in Faculty Publications from Nebraska Center for Materials and Nanoscience by an authorized administrator of DigitalCommons@University of Nebraska - Lincoln. 
Published in Journal of Applied Crystallography 38:3 (June 2005), pp. 576-577; doi: 10.1107/S0021889805009568

Copyright $\odot 2005$ International Union of Crystallography; published by Wiley-Blackwell. Used by permission.

Submitted January 10, 2005; accepted March 24, 2005.

\title{
$J E C P / H O L Z$ - An interactive computer program for simulation of HOLZ patterns
}

\author{
X. Z. Li \\ Center for Materials Research and Analysis, University of Nebraska-Lincoln, NE 68588, USA; email xli2@unl.edu
}

Keywords: HOLZ line, electron diffraction, computer programs

\section{The crystallographic problem}

Because a HOLZ (higher-order Laue zone) line corresponds to a HOLZ reflection that is described by long reciprocal vector $|\mathbf{g}|$, the position of the line will be very sensitive to the lattice parameters. HOLZ line patterns have been used in many areas of the microanalysis of materials, e.g. lattice parameters, strain, local chemical composition, electron potential. Nevertheless, these applications need the aid of computer programs for the simulation of HOLZ line patterns (Sung \& Williams, 1991, and references therein). Software packages for the simulation of HOLZ patterns have been presented, for example, by Zuo (1992), Jouneau \& Stadelmann (1998) and Völkl (1998).

A HOLZ line in the kinematical approximation is the locus of the Bragg condition for a HOLZ reflection $\mathrm{g}$. The position of a HOLZ line calculated from the kinematical approximation deviates slightly with respect to the experimental ones due to the dynamical scattering effect of electron diffraction.

Early computer programs for HOLZ lines were written under the kinematical approximation (Tanaka \& Terauchi, 1985; Eades et al., 1993) and later a first-order dynamic correction was applied in programs to take account of the dynamic lineshift effect (Lin et al., 1989; Bithell \& Stobbs, 1989; Zuo, 1992).

In the present work, an interactive computer program for simulation of the HOLZ line patterns, JECP/HOLZ, is reported. ${ }^{1}$ A feature of this program is the integration of the simulation of the HOLZ reflections and the HOLZ (curved and straight) lines, which is interactive with respect to changes of the lattice parameter, the accelerator voltage, the zone axis, and the beam tilt. The program can be used as a teaching aid for students as well as a tool for scientists working on electron diffraction experiments.

\section{Method of solution}

One method to calculate the position of HOLZ line is to fix the position of a HOLZ line by determining the point at which the line is closest to the zone axis and drawing a line through that point, perpendicular to a vector from the point to the origin, which is described in the textbook by Graef (2003). Another method is to consider the wavevector $\mathbf{k}$ with planar components $k_{t}\left(k_{x}, k_{y}\right)$ and a vertical component $k_{z}$. An equation for $\left(k_{x}, k_{y}\right)$ derived from the Bragg law describes the trajectory of the HOLZ line. This method is described in the textbook by Spence \& Zuo (1992). A third method was used in the early work by Tanaka \& Terauchi (1985), in which the curved HOLZ line is drawn as the trace of the HOLZ reflection disk intersecting the Ewald sphere. A short review of the geometrical interpretation of the formation of the HOLZ lines is also available (Li, 2005).

In this program, the second and third methods have been adopted for the simulation of the straight and curved HOLZ lines. The positions of the HOLZ lines are calculated using the kinematical approximation and the first-order dynamic correction.

It is straightforward to use this program, guided by its well designed graphical user interface (GUI). The program features include simulation of HOLZ reflections and of HOLZ lines (straight and curved line), which are interactive processes depending on the wavelength (or high voltage), the direction of the incident electron beam (or Laue center) and the lattice parameters. There is an option to show indexing of HOLZ reflections and/or lines.

\section{Program specification}

The program is written in Java using the J2SE Software Development Kit (SDK) from Sun Microsystems, Inc.: http:/ / www. sun.com $/ \mathrm{j} 2 \mathrm{se} /$. The program was designed and tested under Microsoft Windows 98SE and XP.

\section{Software and hardware environment}

For executing JECP/HOLZ, a Java virtual machine, i.e. the J2SE Java Runtime Environment (JRE), must be installed on the computer. No special hardware is required.

\section{Documentation and availability}

The program in compressed form (jecp_holz.zip), including a specification file, is available at http://www.unl.edu/ CMRAcfem/XZLI/programs.htm . A registration code can be obtained via e-mail (xli2@unl.edu) from the author. Without a registration code, this program works in demonstration mode only. 


\section{References}

Bithell, E. G. \& Stobbs, W. M. (1989). J. Microsc. 153, 39-49.

De Graef, M. (2003). Introduction to Conventional Transmission Electron Microscopy. Cambridge University Press.

Eades, J. A., Moore, S., Pfullmann, T. \& Hangas, J. (1993). Microsc. Res. Technol. 24, 509-513.

Jouneau, P.-H. \& Stadelmann, P. (1998). http://cimesg1.epfl. $\mathrm{ch} / \mathrm{CIOL} / \mathrm{ems} . \mathrm{html}$

Li, X. Z. (2005). J. Mater. Educ. Submitted.

Lin, Y. P., Bird, D. M. \& Vincent, R. (1989). Ultramicroscopy, 27, 233-240.
Spence, J. C. H. \& Zuo, J. M. (1992). Electron Microdiffraction. New York: Plenum Press.

Sung, C. \& Williams, D. B. (1991). J. Electron Microsc. Tech. 17, 95-118.

Tanaka, M. \& Terauchi, M. (1985). Convergent-Beam Electron Diffraction. Tokyo: Jeol.

Völkl, R. (1998). Electron Microscopy 1998: Proceedings of the 14th International Congress on Electron Microscopy, Cancun, Mexico, 31 August-4 September 1998, Vol. II, edited by H. A. Calderon Benavides and M. José Yacaman, pp. 39-40. Bristol: IOP.

Zuo, J. M. (1992). Ultramicroscopy, 41, 211-223. 